\title{
Phenomenological Study: Grieving Process And Coping Of Mothers With Premature Infant In Neonatal Intensive Care Unit
}

\author{
Anafrin Yugistyowati
}

Department of Nursing, Faculty of Health Sciences, Alma Ata University,

Jl. Brawijaya No. 99, Tamantirto, Yogyakarta

Email: anafrin22_ners@yahoo.co.id

\begin{abstract}
Abstrak
Kelahiran bayi prematur adalah proses yang memberikan dampak ketidaksiapan fisik, sumber stres, dan efek trauma bagi orang tua. Sebagian besar ibu menunjukkan pengalaman yang tidak menyenangkan sehingga mengganggu kemampuan orang tua untuk merawat bayi prematur. Tujuan penelitian ini adalah untuk mengeksplorasi pengalaman proses berduka dan koping ibu selama perawatan masa awal di ruang rawat intensif neonatus. Penelitian kualitatif ini dengan pendekatan fenomenologis menggunakan delapan partisipan. Analisis data yang digunakan dalam penelitian ini adalah Colaizzi. Hasil penelitian adalah proses berduka dengan berbagai gambaran koping diri selama perawatan bayi di ruang rawat intensif neonatus. Hasil penelitian ini merekomendasikan perawat profesional untuk melakukan pengkajian terhadap orang tua (ibu). Prinsip perawatan yang berpusat pada keluarga sangat penting dalam membantu orang tua mengembangkan hubungan terapeutik, memberikan dukungan emosional, dan memberikan informasi yang akurat dan jelas kepada orang tua.
\end{abstract}

Kata Kunci: Proses Berduka, Koping Ibu, Perawatan Bayi Prematur

\begin{abstract}
The premature birth of infants is a process that leads to physical unpreparedness, sources of stress, and traumatize effects for the parents. Mostly mothers showed unpleasant memories that interfered the parents'ability to take care of their premature baby. The aim of this study was to explore experience of grieving process and mothers coping during early life care in neonatal intensive care unit. This qualitative research with phenomenological approach used eight participants. Data analysis used in this research was Colaizzi. The result was the grieving process with various self-coping overview during baby care in the neonatal intensive care unit. The result of this study recommended professional nurses to conduct an assessment toward parents (the mother). The principle of family centeredcare was very important in helping parents to develop therapeutic relationships, providing emotional support, and providing accurate and clear information to parents.
\end{abstract}

Keywords: Grieving Process, Mothers Coping, Premature Infant Care

Article info:

Article submitted on March 10, 2018

Articles revised on April 23, 2018

Articles received on May 30, 2018

DOI: http://dx.doi.org/10.21927/jnki.2018.6(2).160-167 


\section{INTRODUCTION}

The experience of having a premature infant has a long lasting impact on the lives of parents. When a baby is born prematurely, the mental state and the process of becoming a parent are distracted. Parents are not ready physically, psychologically, and emotionally for this condition. Premature birth changes the behavior of the parents because they are exposed to the roles and the responsibilities for their premature infant care in the neonatal intensive care unit. The physical condition of the parents becomes tired and even annoyed as the effects of their responsibility when they have to take care of their baby in the hospital. Having a premature infant also causes shock, feeling of sadness and loss. Those emotions sometimes are very strong. Maybe some parents have difficulty to handle this situation well $(1,2)$

The experience of premature infant hospitalization in NICU can inhibiting the process of parents-baby interaction and attachment. This is because the parent-infant separation causes stress for parents and families who are involved (2). The experience of hospitalization in NICU also has negative impacts on the psychological condition of the parents and the development of the premature infant in the future. Those negative impacts are high levels of anxiety, symptoms of depression, loss of confidence in the care of the baby because of the lack of information, and overprotective care (3).

In addition, the condition of the unfamiliar nursery with a wide variety of complex and awful equipment makes parents of premature infant experiencing high levels of stress and feeling of helplessness in NICU. Parents' psychological stress combined with the lack of sufficient information and knowledge about how parents interact with their babies during hospitalized. Thus, parents often experience negative feeling, difficulty in interacting, and inability to perform care and upbringing of the baby. These conditions will be worsened by the presence of depressive symptoms and dysfunctional parenting disorders after hospitalization $(3,4)$.

The main psychological problem experienced by parents is the psychological stress associated with the condition of the baby with special care in NICU, or babies' physical problem and family social problem. A qualitative study entitled "Fathers' experiences in the neonatal intensive care unit: A search for control", about the psychological stress in fathers with premature babies showed that the fathers suffered lack emotional control when they had a baby with the condition of serious illness, or a premature infant in NICU (5). Another study entitled "Experiences of having a prematurely born infant from the perspective of mothers in Northern Sweden", conducted by Lindberg and Ohrling, their research was qualitative study, showed that the mothers were not ready to have a baby born prematurely, and they had difficulty becoming a mother in the early postpartum. Mothers experienced feeling of anxiety at the separation from their baby and they considered the proximity with their baby was very important (6).

The previous description indicated that grieving process and mothers coping in the care of premature babies in NICU are different. This phenomenon still happens many times and needs special attention from the health care team ${ }^{3}$. Depth understanding of parents' (mother) experience about grieving process and mothers coping is expected to expand the horizons of nurses in nursery in providing nursing care to patients and families. Later, they are be able to develop the strategy of the best solution to resolve problems faced by parents and are able to improve quality of nursing services through nursing care in premature babies, parents, and families in a comprehensive manner (7).

The aim of this study is to explore mother's experience of grieving process and mothers 
coping during early life care in a neonatal intensive care unit.

\section{MATERIALS AND METHODS}

This study used qualitative research design with a phenomenological approach. Participants in this study were parents (mothers) with a premature infant hospitalized in the neonatal intensive care unit RSUP (Hospital) Dr. Soeradji Tirtonegoro Klaten.

Selection of participants was done through purposive sampling technique with the inclusion criteria, they were: 1) mothers who had a premature infant (gestational age $<37$ weeks regardless of birth weight), it was not a care for repeat visits, and they were willing to become a research respondent, 2) mothers who had experience in taking care for a baby in the neonatal intensive care unit for at least 3 days, 3 ) mothers who had a premature infant hospitalized in a neonatal intensive care unit during the first 14 days of life, 4) mothers who had a premature infant in a neonatal intensive care unit with certain conditions that required for a short break at home or took turns with other family members while taking care for their baby in the hospital, 5) mothers who had a premature infant with or without a ventilator (mechanical ventilation), and 6) mothers who were able to communicate and to tell their experience better in Indonesian or in local language (Javanese) that was understood by the participants and the researcher. In this study, the researcher involved eight participants based on the data saturation.

In this study, the researcher served as the primary instrument in the data collecting process. The data collection was done by in-depth interviews to the participants, and the researcher also used the secondary instruments in the research data collection (the voice recorder using MP4, interview guidelines, and field notes).

There were three stages of data collection procedure, they were: 1 ) the preparation phase, where the researcher had obtained a permit and had socialized by doing a presentation in the research place, 2) the implementation phase, it was in-depth interviews with the participants for 30 minutes to 60 minutes, and 3 ) the termination stage, the researchers conducted a clarification and validation of data analysis that had been obtained to ensure the researcher that the analysis result was in accordance with the experiences of the participants and to ensure the credibility of the results.

Reliability and validity of research data were done by showing and asking back to the participants about the description of the data whether they were consistent with the experiences of the participants or not. In this study, the researcher applied four criteria for obtaining the validity of the data, they were: the degree of confidence (credibility), transferability, certainty (confirm ability), and dependability (8).

Mothers' experience during the treatment of premature babies in the neonatal intensive care unit was a sensitive aspect for the mothers, so that the principles of ethical considerations were necessary to ensure that there were no infringement of the participants during the study conducted. This study used some ethical principles of respect for human dignity, they were: the principle of autonomy, beneficence, non-maleficence, anonymity, and justice (9).

\section{RESULTS AND DISCUSSION}

In this study, it can be seen the phenomenon of mothers experience about the process of grieving and mothers coping during early life care in a neonatal intensive care unit. The grieving process for the treatment of premature infants in the neonatal intensive care unit is represented by denial, bargaining and acceptance stages.

Participants who experienced the stages of the grieving process of denial have the unpreparedness perception and denial that the 
baby was born prematurely and had to undergo treatment in a neonatal intensive care unit. The rejection of the grieving process is illustrated in the following statements:

“... dipikir-pikir mbak'e saya masih belum terima, kok Allah itu gak sayang lagi sama aku, kok Allah gini, ujian apa lagi yang dikasih ..." (P2)

[“...if I think it through, Mbak, I still can't take it, how Allah doesn't love me anymore, how Allah is (doing a thing) like this, what test is He giving to me..." (P2)]

“... kok anak saya kayak gitu, udah orang biasa masak dikasih cobaan kayak gitu, kasihan dia gak tahu apaapa, klo emang dikasih sakit biar saya saja ..." (P4)

[ "...how could my child be like that, I am a commoners, how can I be given this kind of problem, it's a pity that my child doesn't know anything, if my child has to be sick I would rather it could be me..." (P4)]

Stages of the grieving process: bargaining is described in this statement from the following participants:

“... yaa klo maunya jangan sampai diambil anakku, dua-duanya pengen hidup mbak. ... klo bisa bertahan hidup aku akan merawat anakku hatihati lagi mbak ..." (P1)

[“...well, (what I) want is for my children to be not taken (by God), both want to live, Mbak, if (they) could stay alive I will take care of them more carefully, Mbak..." (P1)]

“... Ya Allah klo diberi sakit biar saya saja, anak itu gak salah, aku kadang doa gitu mbak ..." (P7)

["... O Allah, if (You) give illness let it be mine, my child is innocent, I sometimes pray like that, Mbak..." (P7)]
Stages of the grieving process: acceptance (acceptance) is expressed on all participants. All participants express the feelings of surrender and acceptance with their condition now with the care of premature infants in the neonatal intensive care unit. As for some of the statements that participants described are as follow:

“... udah semaksimal mungkin, udah berusaha, udah berdoa juga, apapun semuanya keputusan yang di atas kita terima saja dengan sabar ..." (P3)

["... it has been the maximum, (we) have tried, (we) have prayed, whatever (happen, it was) the decision of God we will take it patiently..." (P3)]

“.... gak papa aku rela kok ngejalanin ini, aku cuma pasrah, aku bilang sama anakku "Klo Tuhan gak ngijinin kamu hidup ya udah aku ikhlas, tapi klo Tuhan ngijinin kamu hidup yo cepat keluar dari RS ini"...” (P5)

[“... it's okay, I am willing to do this, I just surrender (to God), I said to my child "If God doesn't let you live, I will be sincere, but if God lets you live so (let's) get out from this hospital..." (P5)]

“... gak papa anakku sekarang dipasang banyak alat tapi kan nanti bisa sembuh, demi kebaikan kesehatan anak gak papa ..." (P6)

[ "... it's okay that my child's (body) now has to be attached with so many equipments but my child will be cured, (it's) for the child's health and wellbeing, (it's) okay..." (P6)]

Mothers respond psychologically during the treatment of premature infants in the neonatal intensive care unit. This psychological response can be described in stages and the grieving process experienced by the mothers naturally. In her theory, Kubler-Ross explaines that grieving is an emotion that is subjective which is a normal 
response to the experience of loss, among other things: denial, anger, bargaining, depression, and acceptance (10).

Stages and process of the grieving in this study include: 1) the stage of denial, which is manifested by crying, ignoring their own health, and disillusionment with the fate that has been ordained by God, 2) the stage of bargaining, at this stage the participants make an agreement and a promise to God through prayers, namely healing and safety of the baby, 3 ) the acceptance stage, at this stage the mother begin to accept and surrender with patience and a sense of sincerity towards the best decisions made by God.

From the findings of research on this theme, it can be concluded that the stages and process of the grieving experienced by participants vary, it depends on the type of mother's personality, assurance about the baby's recovery, level of support given to the mother, and faith in her religion. According to the results of the researcher' analysis, generally only three stages of the grieving process are experienced by the mother. In the present study, it did not find stages of anger, and depression in participants. This may be associated with a pattern of habit and culture of the Javanese who tend to have the acquiescent ("nerimo") personality characteristics in dealing with problems during the treatment of premature infants in the neonatal intensive care unit.

Mothers self coping is varied in experiencing having premature babies in the neonatal intensive care unit. Self coping expressed by the participants among others: being patient, strengthening themselves, praying, struggling, having positive thinking, sharing stories with other people, and putting a trust in the nursing service.

Being patient is expressed by participants during the the process of overseeing the infant care in a neonatal intensive care unit. This self coping is expressed by the first, second, and sixth participants, It is as stated in the statements below:

"... yaa saya harus sabar, lapang dada, mungkin ini sudah kehendak Allah, saya harus bersabar menunggu keputusan dokter aja ..." (P1)

[“... well. I have to be patient, willingly, maybe it's Allah's will, I have to be patient to wait for the doctor's decision..." (P1)]

“... saya mah cuma bisa sabar aja mbak, yaa suami juga bilang gitu harus sabar doa aja ..." (P6)

[“... I just can be patient, Mbak, well, (my) husband also says so (we) have to be patient (and to) pray..." (P6)]

Self-strengthening is also done by some participants as a form of an attempt to face problems during the treatment of premature infants faced by participants. The participants' statements which support this are revealed by five from the eight participants. Some of them are described as follows:

“... trus klo saya stres, saya gila nanti gimana anak saya mbak, itu pikiran saya untuk terus kuat yaa cuma menguatkan diri aja bisa selesai masalahnya ..." (P3)

[“...so if I'm stressed, I'm crazy, how is my child (going to be), Mbak, that's my thoughts to keep being strong, well (I) just (keep) strengthening myself (hopefully) the problem will finish..." (P3)]

“... gak gak gak ada keluhan capek yang penting anak saya sehat, gitu aja pikiran saya mbak, saya gak ngeluh capek atau apa ..." (P5)

["...no, no, there is no complain of getting tired, (what's) important is that my child is healthy, that's all I think (about), Mbak, I don't complain if I feel tired or anything..." (P5)] 
Another self coping performed by the participants is praying. This is done by all participants expressed through some statements. As for some of the statements of the participants are as follows:

“... yang namanya ibu kan cuma bisa doa aja sama anaknya, doa seorang ibu kan mungkin didengerin, 'mudahmudahan cepat sembuh'lek ku dungo kui wae mbak ..." (P4)

[“... well, a mother can only pray for her children, the prayer of a mother could probably be heard, "hopefully (my child) will recover soon' that's all I have been praying for, Mbak..." (P4)]

“... aku cuma bisa istigfar aja, berdoa yaa semoga bisa, berdoa 'kuatkanlah hambamu ini tolonglah anak-anakku Ya Allah, cepat sembuh' gitu aja ..." (P7)

[“... I can only istighfar, just praying, hopefully (my child) can (recover), praying 'stregthen me, help my children O Allah, to recover soon' just like that..." (P7)]

Struggling is also one of mothers self coping for taking care of premature babies in the neonatal intensive care unit. Self coping is expressed by three participants, namely: first, third, and eight participants. As for the statement of the participants are the following:

“... yaa saya berusaha semaksimal mungkin mbak, udah usaha cari darah ke PMI juga, trus saya yaa berusaha semaksimal mungkin bisa tenang menjalani semua ..." (P1)

[...well I struggle as hard as I can, Mbak, (I) already try to find blood to $\mathrm{PMI}$ also, then I try as hard as possible to be calm in undergoing all this..." (P1)]

“... saya sama suami yaa cuma berusaha semaksimal mungkin biar cepat sehat anak saya ..." (P6)
[“... I and my husband just struggle as hard as possible to make our child be healthy quickly..." (P6)]

Having a positive thinking towards the recovery and safety of premature babies is also one of the participants self coping. A total of three participants from eight participants reveal self coping statements which support it. The statements of the participants can be described as follows:

"... pikiran saya sekarang anak saya sembuh cepat pulang gitu aja mbak, gak ada yang lainnya itu aja ..." (P5)

["...what I am thinking now (is that) my child could recover and be home soon, like that, Mbak, there is nothing else, just that..." (P5)]

“... trus yaa pikiran sekarang gitu 'pasti anak saya sembuh', saya udah berusaha sama suami trus Allah pasti mendengarkan doa saya ...” (P8)

[“... so ya, (my) thoughts now is that 'my child will recover', I have struggled with (my) husband and Allah must listens to my prayer..." (P8)]

To reduce sadness, anxiety, and fear in the hearts, some of the participants share stories to other people that are considered to understand their problem. This self coping is done by three participants through the statements disclosed in the following passage:

“... saya sama suami yaa sering bercerita begini begini begini tentang perkembangan kesehatan anak saya, yaa berbagi suka berbagi duka ..." (P1)

[“... I and mhy husband often share stories like this, this, this about the development of my child's health, well, (we) share happiness and sadness..." (P1)]

“... kadang juga sering bisa ngobrol cerita gitu sama suami yaa sama 
keluarga juga, jadi hati plong, gak sendirian ada orang yang diajak berbagi susah ..." (P7)

[“... sometimes (I) also frequently chat with (my) husband or with (my) family also, so my heart could be relieved, (that I am) not alone (and) there are people who (I) can share (my) hardship with..." (P7)]

As parents of premature babies, participants during the treatment in a neonatal intensive care unit tried to trust the nursing service, both to the doctor, nurse, or other health professionals. This was expressed by some participants is as follows:

“... saya harus percaya sama perawat karena dia yang merawat anak saya, menurut aja apa kata dokter apa kata perawat di sini ..." (P2)

["... I have to trust the nurse because she is the one who takes care of my child, just obey what the doctor says what the nurse says here..." (P2)]

“... yang namanya medis semaksimal mungkin udah dikasih obat yang bagus gitu, masalah medis kan urusannya dokter sama perawat di sini mbak, udah percaya aja udah dirawat di sini ya udah ..." (P3)

[“... it's medical so maybe (they have) given a good medication, medical problems are the doctors and the nurses business here, Mbak, (we) just trust (them because our child) is hospitalized here, so there we are..." (P3)]

Mothers with experience of grief would normally use a coping to overcome the problems tey are facing. One of the afformentioned copings can come from the mother's self (personal coping) (11). The theory of "chronic sorrow" discusses the problems that arise from chronic disease include the process of grieving, lost, precipitating factors and management strategies (9). Management strategies can be done internally or externally. Self-care management strategies are designed as internal coping strategies, including: action, cognitive, interpersonal and emotional. This management strategy is said to be effective if an individual shows that her sad feelings has decreased (12). The other management strategy is family centered care (FCC) in the threatment of premature infant and grieving process. There is a significant difference in control and intervention group.FCC Programme can be a model of nursing intervention that implication of this research (13).

According to the results of the researcher analysis, in this study is described seven self copings performed by mothers during infant care in a neonatal intensive care unit. As for the mother copings, among other things: being patient, strengthening themselves, praying, struggling, having a positive thinking, sharing stories with others, and putting trust in the nursing service. Various self coping is described by the mothers in this research is a form of activity that aims to reduce the psychological burden of anxiety, worry, fear, sadness, and a feeling of helplessness experienced by the mother. Coping with it will foster confidence in the recovery and safety of their babies.

Some researches have also explained about parents coping with premature babies to resolve psychological problems encountered during the treatment in the NICU. It is showed in the result that in order to regain a good emotional control, mothers must often be engaged in directed activities, always think positive, communicate problems with people who understand the condition, and always pray to God with her faith (14).

\section{CONCLUSION}

Mother's reaction during the treatment of premature infants early life that is the grieving 
process with an overview of various self coping during the infant care in a neonatal intensive care unit.

The process of grieving and self coping of the mother are things that need to be studied more deeply. Attention from nurse to the individual problem of mother requires an individual assessment to obtain intervention which is in accordance with the experiences felt by the mother. This will create a relationship of communication and nursing care that involves families to run well. The principles of treatment in premature infants is intended to involve parents as partners in care (family centered-care), as well as helping them to establish a good bond with their baby. The intervention will help the family and the nursing staff to work in the child care. Nurses play an important role in helping parents to develop therapeutic relationships, providing emotional support, providing accurate and clear information to parents and involving parents in the care of her baby. Nurses are expected to play an important role to help parents to talk and discuss the issues, and facilitate parents to be closer to their baby.

\section{REFERENCES}

1. Cleveland, L.M. (2008). Parenting in the neonatal intensive care unit. JOGNN, 37 (6), 666-691.

2. Lindberg, B., \& Ohrling, K. (2008). Experiences of having a prematurely born infant from the perspective of mothers in northern sweden. International Journal of Circumpolar Health, 67 (5), 461-471.

3. Kearvell, H., \& Grant, J. (2008). Getting connected: How nurses can support mother / infant attachment in the neonatal intensive care unit. Australian Journal of Advanced Nursing, 27 (3), 75-82.

4. Heneghan, A.M., Chaudron, L.H., Isser, A.S., Park, E.R., \& Kelly, J. (2007). Factors associated with identification and management of maternal depression pediatricians. Pediatrics, 119, 444-454.

5. Arockiasamy,V., Holsti, L., \& Albersheim, S. (2008). Fathers' experiences in the neonatal intensive care unit: A search for control. Pediatrics, 121 (2), 215-221.

6. Lindberg, B., \& Ohrling, K. (2008). Experiences of having a prematurely born infant from the perspective of mothers in northern sweden. International Journal of Circumpolar Health, 67 (5), 461-471.

7. Kearvell, H., \& Grant, J. (2008). Getting connected: How nurses can support mother / infant attachment in the neonatal intensive care unit. Australian Journal of Advanced Nursing, 27 (3), 75-82.

8. Polit, D.F., Beck, C.T., \& Hungler, B.P. (2006). Essential of nursing research: Methods, appraisal, and utilization. (6th ed.). Philadelphia: Lippincot.

9. Tomey, A.M., \&Alligood, M.R. (2006). Nursing theorists and their work. (6th ed.). St. Louis: Mosby Inc.

10. Videbeck, S.L. (2008). Buku ajar keperawatan jiwa. (Komalasari, R., \& Karyuni, P.E., Penerjemah.). Jakarta: EGC.

11. Obeidat, H.M., Bond, E.A., \& Callister, L.C. (2009). Parental experience of having an infant in the newborn intensive care unit. The Journal of Perinatal Education, 18(3), 23-29.

12. Perry, S.E., Hockenberry, M.J., Lowdermilk, D.L., \& Wilson, D. (2010). Maternal child nursing care. (4th ed.). Missouri: Mosby Elsevier.

13. Yugistyowati, A. (2016). Penerapan Family Centered-Care (FCC) Pada Program Pendampingan Keluarga Terhadap Length Of Stay (LOS) Perawatan Bayi Prematur. Medika Respati.

14. Shah, P.E., Clements, M., \& Poehlmann, J. (2011). Maternal resolution of grief after preterm birth: Implications for infant attachment security. Pediatrics, 127, 284-292. 